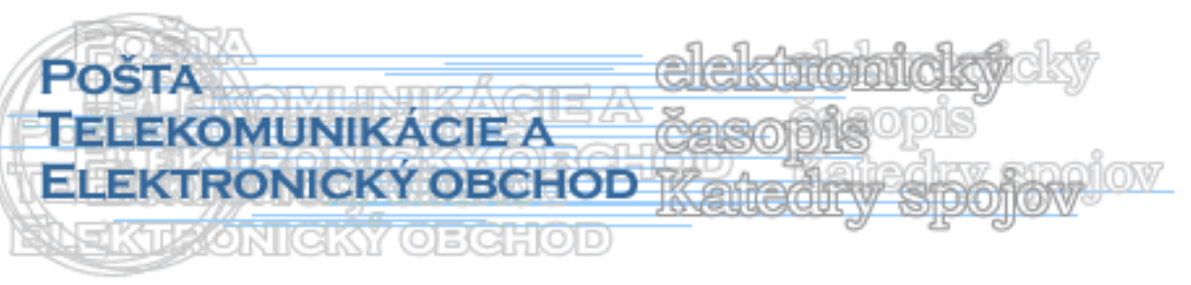

\title{
ANALÝZA VYUŽÍVANIA SLUŽIEB MOBILNÝCH OPERÁTOROV ŠTUDENTMI
}

\author{
Margita Majerčáková ${ }^{1}$, Anna Pad'ourová ${ }^{2}$
}

Úvod

Komunikácia je jednou z dôležitejších súčastí života každého z nás. Telekomunikační operátori, ktorí ponúkajú svoje služby sa svojou ponukou snažia zaujat' určité skupiny užívatel'ov. Významnú skupinu užívatel'ov tvoria mladí l'udia. Správne oslovenie tejto skupiny užívatel'ov operátorom zvýši využitel'nost' ponúkaných služieb.

\section{Využívanie služieb mobilných operátorov}

Analýzu súčasného stavu je možné uskutočnit' prostredníctvom prieskumu, ktorý bol vykonaný v rámci diplomovej práce [1]. Do prieskumu sa zapojilo 103 študentov strednej a vysokej školy v čase od 26. marca do 8. apríla 2009, z ktorých bolo 51 študentov strednej školy a 52 študentov vysokej školy. Dotazník obsahoval 15 otázok. Návratnost' bola 100\% hlavne z dôvodu osobného dotazovania.

\section{Výsledky prieskumu:}

Znenie otázky: Ste uživatel’om predplatenej karty alebo paušálu?

Vyhodnotenie otázky je znázornené na obrázku č. 1, z ktorého vyplýva, že študenti častejšie využívajú paušál ako predplatenú kartu aj ked' pre rôzne kategórie študentov je to odlišné (Tabul'ka č. 1).

Tabul'ka č. 1

Druh služby používanej študentmi

\begin{tabular}{|l||c|c|c|}
\hline Druh služby & Študent strednej školy & Študent vysokej školy & Spolu \\
\hline Predplatená karta & 29 & 15 & 44 \\
\hline Paušál & 21 & 37 & 58 \\
\hline
\end{tabular}

\footnotetext{
1 Dr. Ing. Margita Majerčáková, Katedra spojov, Fakulta prevádzky a ekonomiky dopravy a spojov, Žilinská univerzita v Žiline, Univerzitná 1, 01026 Žilina, Slovenská republika, tel.: +421415133126, fax:

+421415655615 e-mail: Margita.Majercakova@fpedas.uniza.sk

2 Ing. Anna Pad'ourová, PhD., Žilinská univerzita v Žiline, Fakulta prevádzky a ekonomiky dopravy a spojov, Katedra spojov, Univerzitná 1, 01026 Žilina, tel.: 041/5133129, fax: 041/5655 615, e-mail: Anna.Padourova@fpedas.uniza.sk
} 


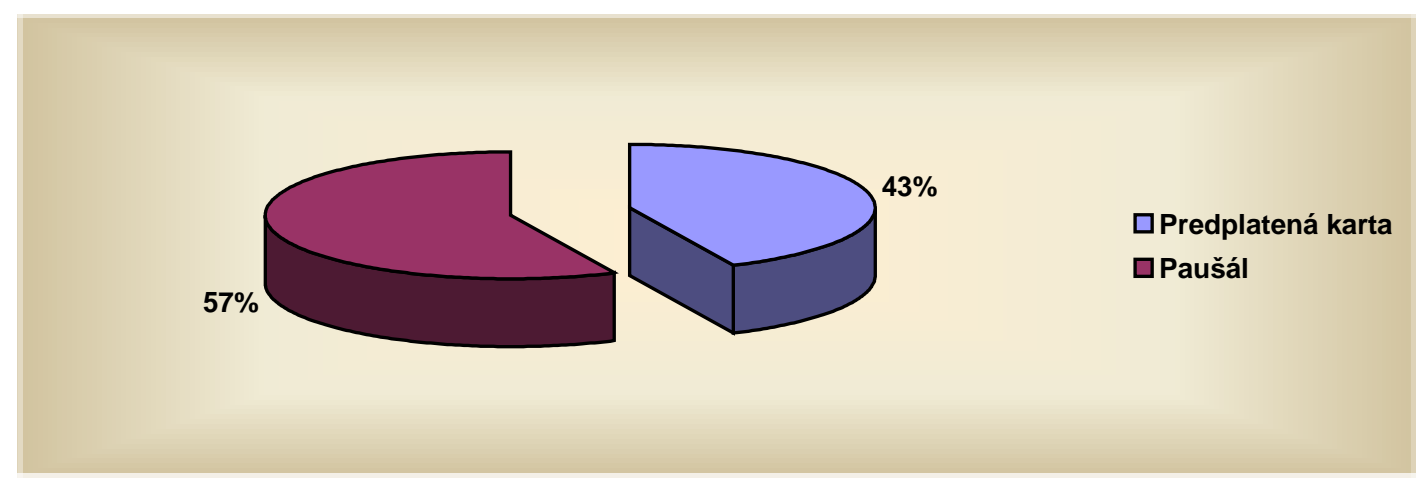

Obrázok č. 1 Druh služby používanej študentmi

Znenie otázky: Zákazníkom ktorej spoločnosti ste?

Na Obrázku č. 2 vidíme, že najviac študentov využíva služby spoločnosti T-Mobile Slovensko, a. s. Výsledky ovplyvnili hlavne študenti strednej školy.

Tabul'ka č. 2

Operátor využívaný študentmi

\begin{tabular}{|l|c|c|c|}
\hline Mobilný operátor & Študent strednej školy & Študent vysokej školy & Spolu \\
\hline Orange Slovensko, a. s. & 17 & 24 & 41 \\
\hline T-Mobile Slovensko, a. s. & 30 & 23 & 53 \\
\hline Telefónica O2 Slovakia, s. r. o. & 4 & 5 & 9 \\
\hline
\end{tabular}

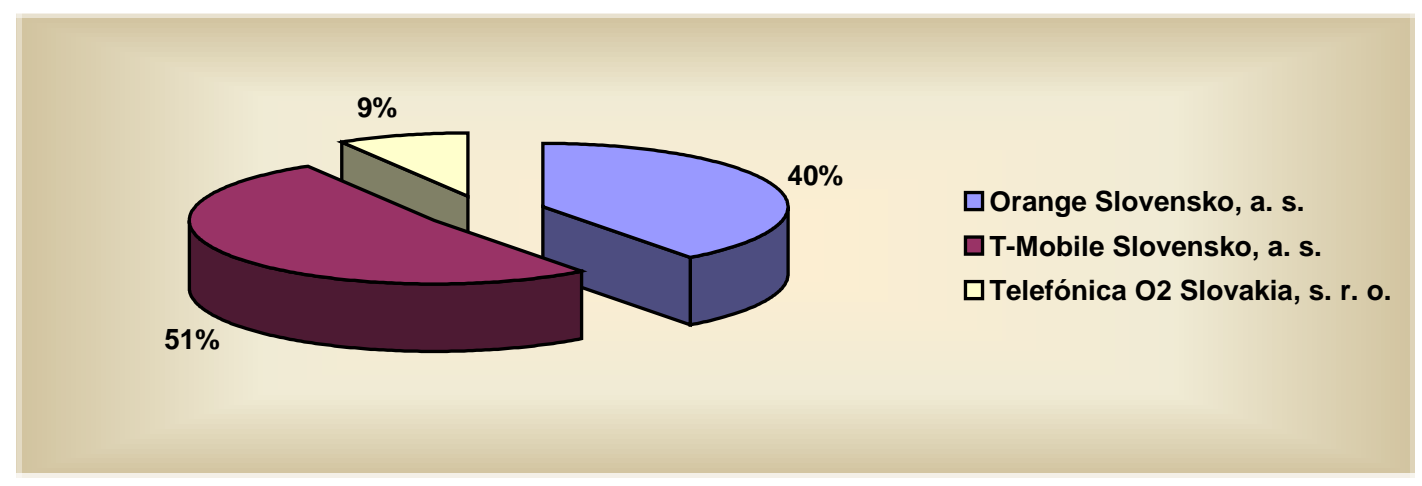

Obrázok č. 2 Mobilný operátor využívaný študentmi

Znenie otázky: Ste spokojný so svojím operátorom?

Študenti sú so službami svojho mobilného operátora vo väčšine „skôr spokojní“ (Tabul'ka č. 3 a Obrázok č. 3).

Tabul'ka č. 3

Úroven̆ spokojnosti študentov so svojim operátorom

\begin{tabular}{|l|c|c|c|}
\hline Úroveň spokojnosti & Študent strednej školy & Študent vysokej školy & Spolu \\
\hline Vel'mi spokojný & 18 & 10 & 28 \\
\hline Skôr spokojný & 22 & 34 & 56 \\
\hline Skôr nespokojný & 7 & 8 & 15 \\
\hline Vel'mi nespokojný & 4 & 0 & 4 \\
\hline
\end{tabular}




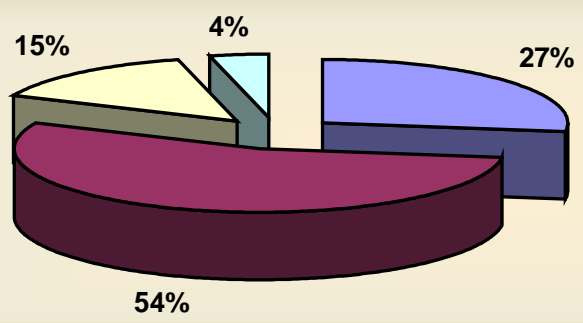

$\square$ Vel'mi spokojný

$\square$ Skôr spokojný

口Skôr nespokojný

口Vel'mi nespokojný

$54 \%$

Obrázok č. 3 Úroveň spokojnosti študentov so svojim operátorom

Znenie otázky: Boli by ste ochotný zmenit' operátora pri výhodnejšej ponuke?

Celkovo sú študenti ochotní zmenit' svojho operátora (Tabul'ka č. 4 a Obrázok č. 4).

Tabul'ka č. 4

Ochota zmenit' operátora pri výhodnejšej ponuke

\begin{tabular}{|l|c|c|c|}
\hline Ochota zmenit’ operátora & Študent strednej školy & Študent vysokej školy & Spolu \\
\hline Áno & 17 & 26 & 43 \\
\hline Nie & 12 & 8 & 20 \\
\hline Záleží na podmienkach & 22 & 18 & 40 \\
\hline
\end{tabular}

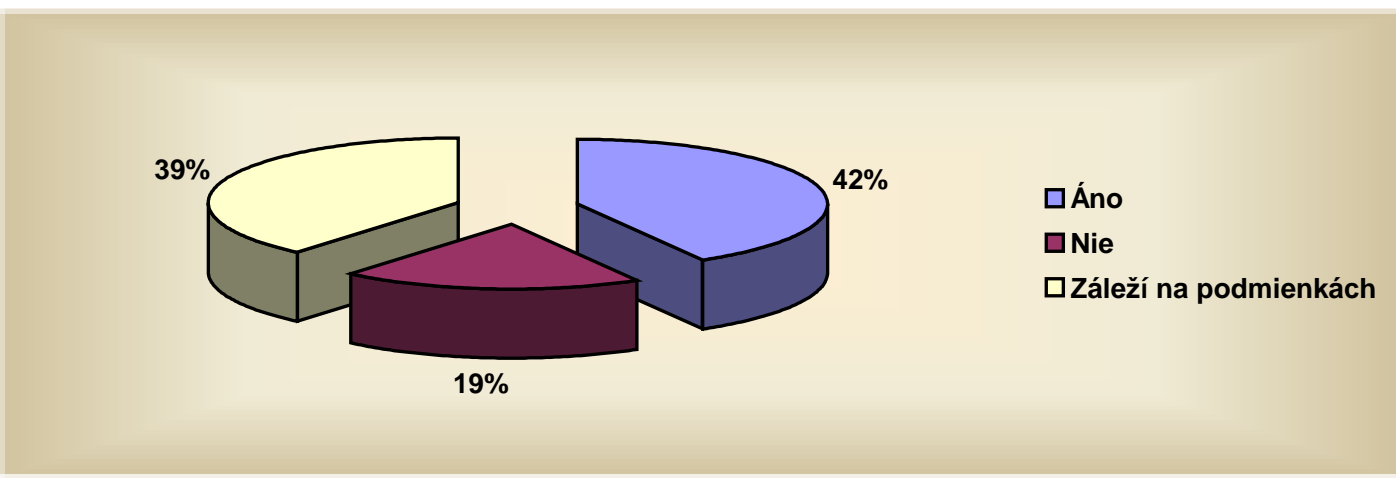

Obrázok č. 4 Ochota zmenit’ operátora pri výhodnejšej ponuke

Znenie otázky: Aké služby najčastejšie využívate?

Telefonovanie spolu s SMS patrí medzi najoblúbenejšie služby medzi študentmi (Tabul'ka č. 5 a Obrázok č. 5).

Tabul'ka č. 5

Najčastejšie využívané služby

\begin{tabular}{|l|c|c|c|}
\hline Druh služby & Študent strednej školy & Študent vysokej školy & Spolu \\
\hline Telefonovanie & 42 & 46 & 88 \\
\hline SMS & 41 & 36 & 77 \\
\hline MMS & 1 & 2 & 3 \\
\hline Dátové služby & 1 & 2 & 3 \\
\hline
\end{tabular}




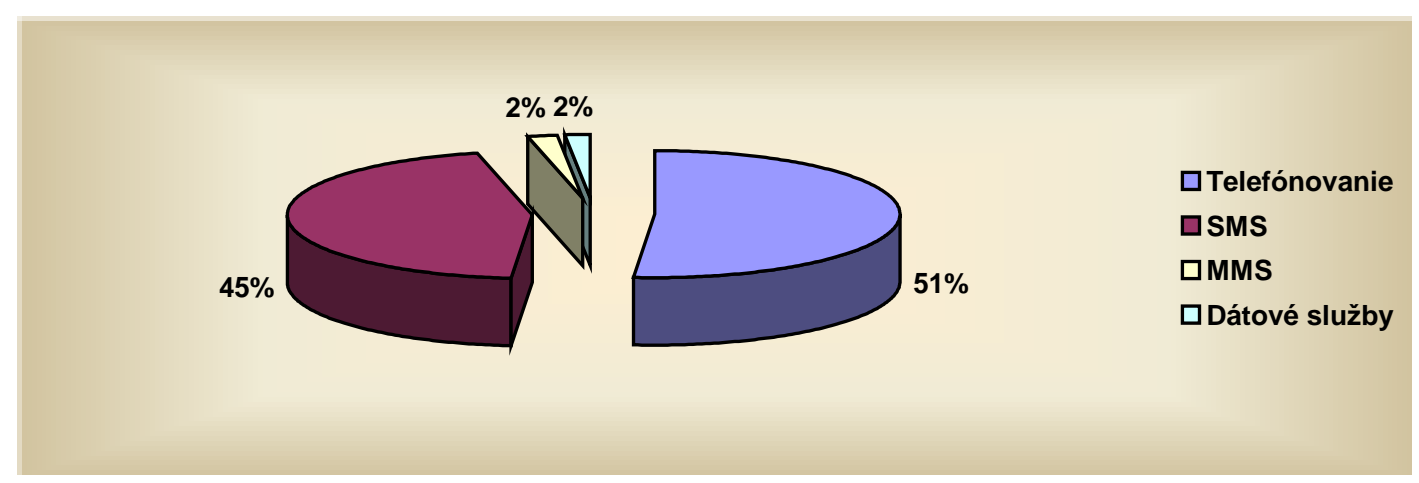

Obrázok č. 5 Najčastejšie využivané služby

\section{Znenie otázky: Kol'ko minút mesačne pretelefonujete?}

Vo väčšine študenti strednej školy pretelefonujú mesačne 20 až 40 minút. Študenti vysokej školy najčastejšie mesačne pretelefonujú 100 a viac minút (Tabul'ka č. 6). Celkovo najčastejšie študenti mesačne pretelefonujú 100 a viac minút (Obrázok č. 6).

Tabul'ka č. 6

Počet mesačne pretelefonovaných minút

\begin{tabular}{|l|c|c|c|}
\hline Počet minút & Študent strednej školy & Študent vysokej školy & Spolu \\
\hline $\mathbf{0}$ & 0 & 0 & 0 \\
\hline $\mathbf{1}$ až 20 & 5 & 7 & 12 \\
\hline $\mathbf{2 0}$ až 40 & 16 & 10 & 26 \\
\hline $\mathbf{4 0}$ až 60 & 7 & 7 & 14 \\
\hline $\mathbf{6 0}$ až 80 & 6 & 5 & 11 \\
\hline $\mathbf{8 0}$ až 100 & 4 & 6 & 10 \\
\hline $\mathbf{1 0 0}$ a viac & 12 & 17 & 29 \\
\hline
\end{tabular}

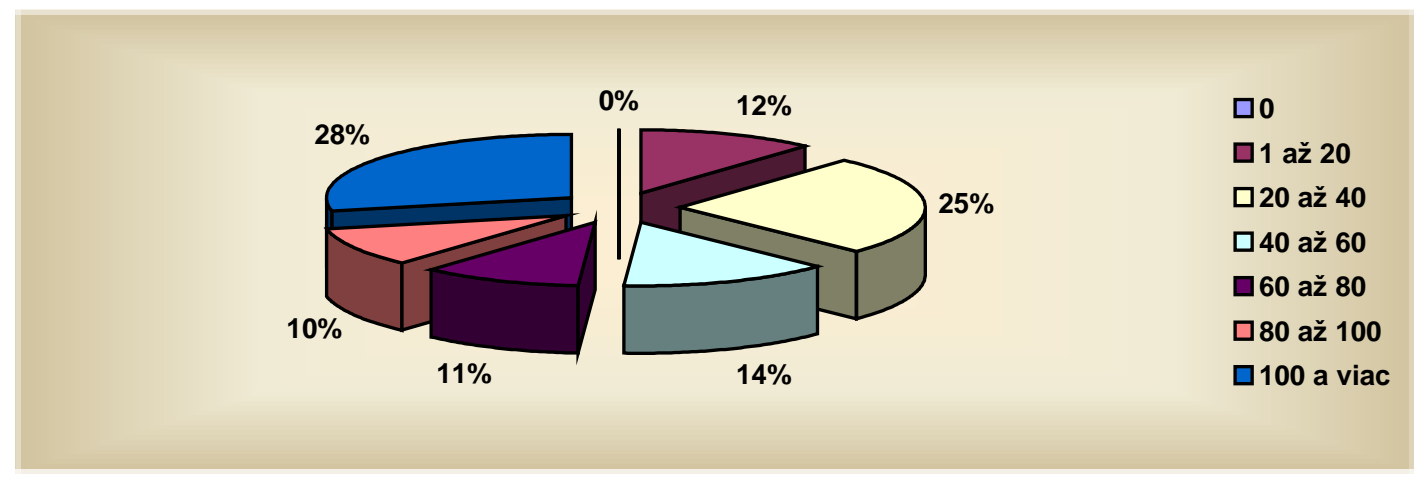

Obrázok č.6 Počet mesačne pretelefonovaných minút

Znenie otázky: Kol'ko SMS mesačne pošlete?

Väčšina študentov pošle mesačne 1 až 20 SMS (Tabul'ka č. 7 a Obrázok č. 7). 
Tabul'ka č. 7

Počet mesačne poslaných SMS

\begin{tabular}{|l|c|c|c|}
\hline Počet SMS & Študent strednej školy & \multicolumn{1}{c|}{ Študent vysokej školy } & Spolu \\
\hline $\mathbf{0}$ & 0 & 0 & 0 \\
\hline $\mathbf{1}$ až 20 & 16 & 32 & 48 \\
\hline $\mathbf{2 0}$ až 40 & 13 & 8 & 21 \\
\hline $\mathbf{4 0}$ až $\mathbf{6 0}$ & 9 & 6 & 15 \\
\hline $\mathbf{6 0}$ až $\mathbf{~ 0 0}$ & 2 & 1 & 3 \\
\hline $\mathbf{8 0}$ až 100 & 3 & 2 & 5 \\
\hline $\mathbf{1 0 0}$ a viac & 8 & 3 & 11 \\
\hline
\end{tabular}

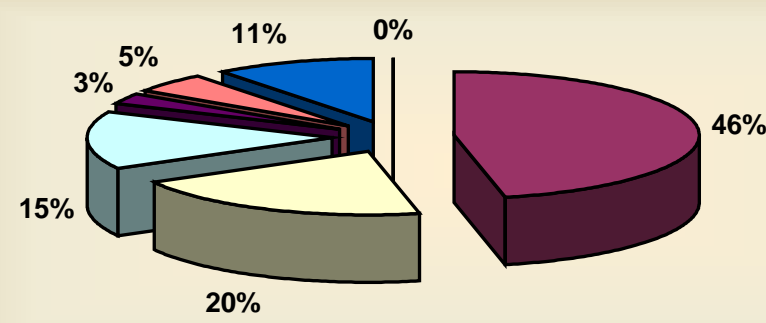

$\square 0$

$\square 1$ až 20

$\square 20$ až 40

$\square 40$ až 60

$\square 60$ až 80

$\square 80$ až 100

$\square 100$ a viac

\section{Obrázok č. 7 Počet mesačne poslaných SMS}

Znenie otázky: Kol'ko MMS mesačne pošlete?

Z prieskumu vyplynulo, že študenti strednej aj vysokej školy najčastejšie nepošlú ani jednu MMS za mesiac. Dá sa povedat', že táto služba celkovo medzi študentmi nie je používaná (Tabul'ka č. 8 a Obrázok č. 8).

\section{Tabul'ka č. 8}

Počet mesačne poslaných MMS

\begin{tabular}{|l|c|c|c|}
\hline Počet MMS & Študent strednej školy & Študent vysokej školy & Spolu \\
\hline $\mathbf{0}$ & 42 & 39 & 81 \\
\hline $\mathbf{1}$ až 20 & 9 & 12 & 21 \\
\hline $\mathbf{2 0}$ až 40 & 0 & 1 & 1 \\
\hline $\mathbf{4 0}$ až 60 & 0 & 0 & 0 \\
\hline $\mathbf{6 0}$ až 80 & 0 & 0 & 0 \\
\hline $\mathbf{8 0}$ až $\mathbf{1 0 0}$ & 0 & 0 & 0 \\
\hline $\mathbf{1 0 0}$ a viac & 0 & 0 & 0 \\
\hline
\end{tabular}




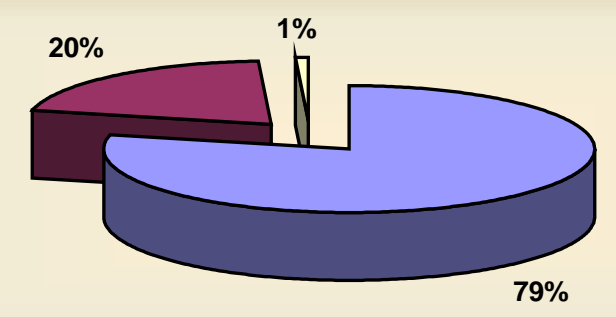

प0

$\square 1$ až 20

प20 až 40

Obrázok č. 8 Počet mesačne poslaných MMS

Znenie otázky: Používate dátové služby, konkrétne internet $v$ mobile?

Študenti strednej aj vysokej školy vo väčšine nepoužívajú internet v mobile. Celkovo teda táto službe nie je medzi dotazovanými využívaná (Tabul'ka č. 9 a Obrázok č. 9).

Tabul'ka č. 9

Používanie dátových služieb, konkrétne internetu v mobile

\begin{tabular}{|l|c|c|c|}
\hline & Študent strednej školy & Študent vysokej školy & Spolu \\
\hline Áno & 9 & 8 & 17 \\
\hline Nie & 41 & 44 & 85 \\
\hline
\end{tabular}

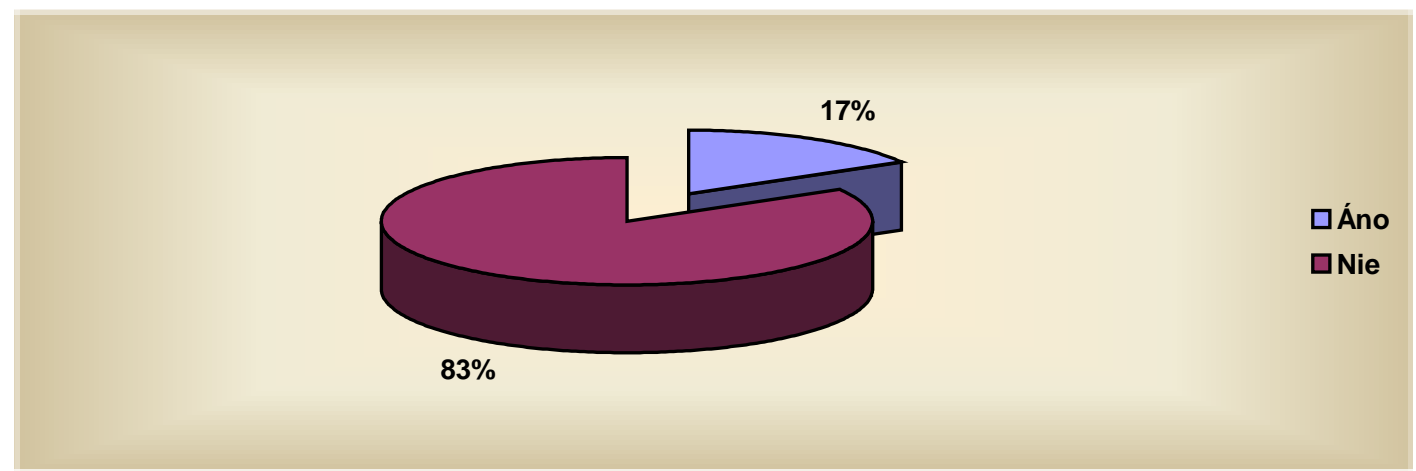

Obrázok č. 9 Používanie dátových služieb, konkrétne internetu v mobile

Znenie otázky: Aká je Vaša mesačná platba za mobilné služby?

Študenti strednej školy aj vysokej školy najčastejšie platia za mobilné služby do $10 €$ za mesiac(Tabul'ka č. 10 a Obrázok č. 10).

Tabul'ka č. 10

Mesačná platba za mobilné služby

\begin{tabular}{|l|c|c|c|}
\hline Suma & Študent strednej školy & Študent vysokej školy & Spolu \\
\hline Do $\mathbf{1 0} €$ & 17 & 16 & 33 \\
\hline $\mathbf{1 0}-\mathbf{1 5} €$ & 13 & 6 & 19 \\
\hline $\mathbf{1 5}-\mathbf{2 0} €$ & 9 & 12 & 21 \\
\hline $\mathbf{2 0}-\mathbf{2 5} €$ & 6 & 8 & 14 \\
\hline $\mathbf{2 5}-\mathbf{3 0} €$ & 3 & 4 & 7 \\
\hline $\mathbf{3 0} €$ a viac & 3 & 6 & 9 \\
\hline
\end{tabular}



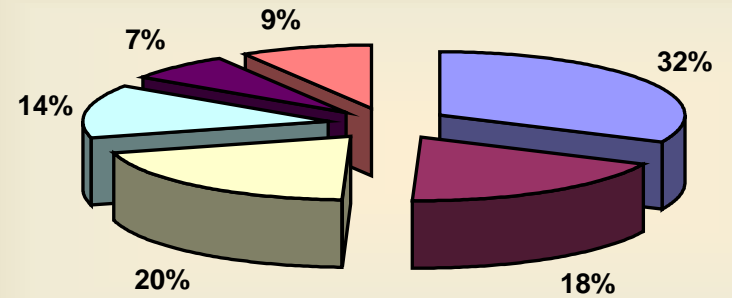

Obrázok č. 10 Mesačná platba za mobilné služby

Znenie otázky: Akú platbu ste ochotný akceptovat?

Mesačná platba, ktorú je ochotných najviac študentov akceptovat' je 10 až $15 €$ (Tabul'ka č. 11 a Obrázok č. 11).

Tabul'ka č. 11

Mesačná platba za mobilné služby, ktorú je ochotný študent akceptovat'

\begin{tabular}{|l|c|c|c|}
\hline Suma & Študent strednej školy & Študent vysokej školy & Spolu \\
\hline Do $\mathbf{1 0} €$ & 13 & 12 & 25 \\
\hline $\mathbf{1 0}-\mathbf{1 5} €$ & 14 & 19 & 33 \\
\hline $\mathbf{1 5}-\mathbf{2 0} €$ & 13 & 9 & 22 \\
\hline $\mathbf{2 0}-\mathbf{2 5} €$ & 5 & 5 & 10 \\
\hline $\mathbf{2 5}-\mathbf{3 0} €$ & 3 & 5 & 8 \\
\hline $\mathbf{3 0} € \mathbf{a}$ viac & 3 & 2 & 5 \\
\hline
\end{tabular}

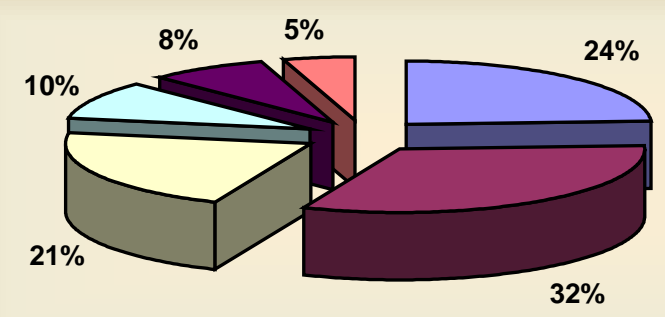

Obrázok č. 11 Mesačná platba za mobilné služby, ktorú sú študenti ochotní akceptovat’

Znenie otázky: Využívate ponuku akciových mobilných telefónov?

Väčšina študentov strednej a vysokej školy využíva ponuku akciových mobilných telefónov (Tabul'ka č. 12 a Obrázok č. 12). 
Tabul'ka č. 12

Úroveň využívania ponuky akciových mobilných telefónov

\begin{tabular}{|l|c|c|c|}
\hline & Študent strednej školy & Študent vysokej školy & Spolu \\
\hline Áno & 27 & 34 & 61 \\
\hline Nie & 24 & 18 & 42 \\
\hline
\end{tabular}

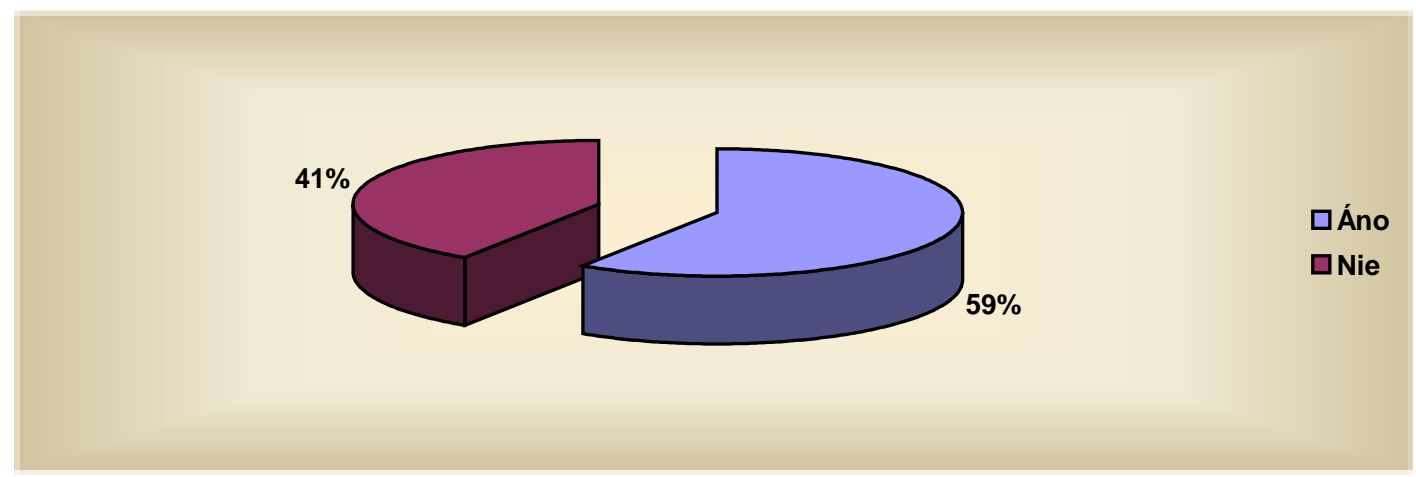

Obrázok č. 12 Úroven̆ využívania ponuky akciových mobilných telefónov

\section{telefónu?}

Znenie otázky: Vyhovuje Vám viazanost’ 2 roky pri využití ponuky akciového

Študentom strednej školy viazanost' 2 roky vyhovuje, naopak, študentom vysokej školy nevyhovuje Celkovo študenti nie sú spokojní s viazanost'ou 2 roky (Tabul'ka č. 13 a Obrázok č. 13).

Tabul'ka č. 13

Spokojnost's viazanost'ou 2 roky pri využití ponuky akciového telefónu

\begin{tabular}{|l|c|c|c|}
\hline & Študent strednej školy & Študent vysokej školy & Spolu \\
\hline Áno & 27 & 21 & 48 \\
\hline Nie & 24 & 31 & 55 \\
\hline
\end{tabular}

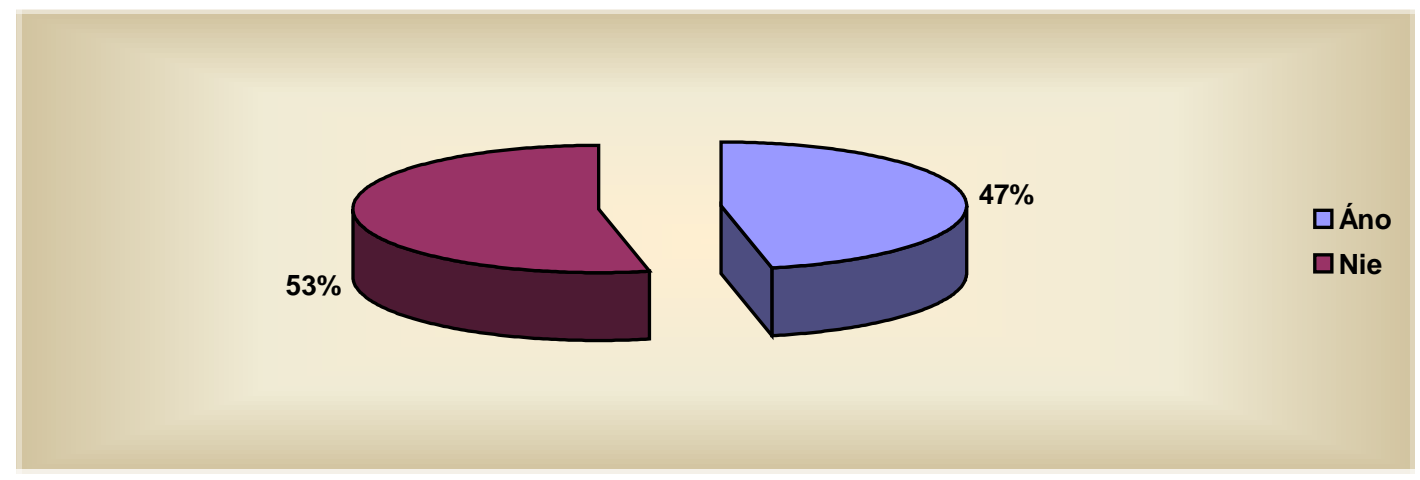

Obrázok č. 13 Spokojnost’s viazanost'ou 2 roky pri využití ponuky akciového telefónu

Znenie otázky: Akú platbu ste ochotný akceptovat’?

Táto otázka ako jediná bola otvorená. Najviac opýtaných, až dvadsat'sedem, odpovedalo, že by prijalo zlacnenie služieb. Dvanást' opýtaných by privítalo širšiu ponuku mobilných telefónov. Viac akcií na všetky služby vrátane internetu v mobile by privítalo sedem opýtaných. Vol'né SMS a MMS chýbajú šiestim opýtaným. Traja opýtaní by privítali 
výhody pre verných zákazníkov, dvaja lepšie pokrytie, dvaja možnost' robit' zmeny počas viazanosti a taktiež dvaja by uvítali kratšiu viazanost'. Medzi d'alšie názory patrila možnost' paušálu bez nutnosti akciového mobilného telefónu, kvalitný servis mobilných telefónov, akciové telefóny bez podmienky viazanosti, darčeky. Dvaja opýtaní sa zhodli, že by uvítali viac serióznosti zo strany mobilného operátora.

\section{Záver}

Na základe dotazníka sme zistili, že respondenti vo všeobecnosti dávajú prednost' paušálu pred predplatenými kartami. Väčšina z nich by privítala zlacnenie služieb a je kvôli tomu ochotná zmenit' svojho mobilného operátora. Študenti podl'a prieskumu často využívajú možnost' akciového mobilného telefónu.

Z dotazníka taktiež vyplynulo, že najobl'úbenejšie služby medzi študentmi sú telefonovanie a posielanie SMS správ. Väčšina študentov strednej školy pretelefonuje mesačne 20 až 40 minút. U študentov vysokej školy je to odlišné. Tí najčastejšie pretelefonujú 100 a viac minút mesačne. Vo všeobecnosti za obe skupiny bol pomer týchto dvoch odpovedí vel'mi vyrovnaný. Pri SMS správach je to u obidvoch skupín rovnaké. Najviac študentov mesačne pošle 1 až 20 SMS správ, aj ked' vel'ké percento študentov strednej školy pošle viac ako 20 SMS správ mesačne.

Z hl'adiska mesačnej platby za mobilné služby boli výsledky dotazníka u študentov strednej aj vysokej školy rovnaké. Obe skupiny študentov sú ochotní akceptovat' mesačnú platbu vo výške maximálne $15 €$.

Výsledky analýzy môžu napomôct' operátorom na mobilnom trhu navrhnút' službu vhodnú pre študentov a tým pádom získat' potencionálnych zákazníkov na dlhšie obdobie.

\section{Literatúra}

[1] HRMELOVÁ, J.: Návrh produktu mobilného operátora pre segment študentov [Diplomová práca]. Žilinská univerzita v Žiline. Fakulta prevádzky a ekonomiky dopravy a spojov; Katedra spojov. Vedúci diplomovej práce: Dr. Ing. Majerčáková Margita.; Žilina: FPEDaS ŽU, 2009.

\section{Grantová podpora}

- VEGA 1/0468/08 Inovačné stratégie v sektore služieb 